\title{
ANALIZA WYNIKÓW BADANIA STÓP BEZROBOCIA WEDŁUG WYKSZTALCENIA W WOJEWÓDZTWIE PODLASKIM
}

\begin{abstract}
Streszczenie
W artykule dokonano krótkiego przeglądu różnych metodologii obliczania stóp bezrobocia, stosowanych przez Główny Urząd Statystyczny w Polsce, a także przedstawiono pomysł pewnej ich modyfikacji. Obliczono stopy bezrobocia według zaproponowanej metodologii $\mathrm{w}$ województwie podlaskim w podziale na rodzaj wykształcenia: wyższe, policealne i średnie zawodowe, średnie ogólnokształcące, zasadnicze (zawodowe) oraz gimnazjalne, podstawowe i niepełne podstawowe. Otrzymane wyniki poddano analizie.
\end{abstract}

Słowa kluczowe: bezrobocie, stopa bezrobocia rejestrowanego, stopa bezrobocia według BAEL, aktywni zawodowo

\section{ANALYSIS OF RESEARCH INTO UNEMPLOYMENT RATES BY EDUCATIONAL ATTAINMENT IN PODLASKIE VOIVODESHIP}

\section{Summary}

The paper provides a brief review of various methodologies for calculating unemployment rates applied by Główny Urząd Statystyczny (Central Statistical Office) in Poland, as well as proposals of certain modifications. Unemployment rates in Podlaskie have been calculated based on the suggested methodology for the following levels of education: tertiary, post-secondary and secondary vocational, secondary general, basic vocational and lower secondary, primary and incomplete primary. An analysis of the results has been conducted.

Key words: unemployment, registered unemployment rate, unemployment rate according to LFS (Labour Force Survey), economically active persons

\section{Wstęp}

W warunkach gospodarki rynkowej bezrobocie uznaje się za jej trwały element. Zjawisko to występuje w gospodarkach całego świata i wywołuje wiele negatywnych skutków [Kozek, 2013, s. 38]. Dotyczy ono osób w różnym wieku. Może dotknąć zarówno ludzi młodych, tuż po ukończeniu edukacji, jak i osoby z wieloletnim stażem na

${ }^{1}$ dr Beata Madras-Kobus - Wydział Ekonomii i Zarządzania, Uniwersytet w Białymstoku; e-mail: b.kobus@uwb.edu.pl; dr hab. Józef Rogowski, prof. UwB - Wydział Ekonomii i Zarządzania, Uniwersytetw Białymstoku; e-mail: rogowski@uwb.edu.pl. 
rynku pracy. Dla pojedynczych osób oznacza to całkowity lub prawie całkowity brak możliwości zarobkowania. Jednak skutki bezrobocia odczuwają nie tylko osoby pozbawione pracy, ale również ich rodziny. Można więc mówić nie tylko o ekonomicznych skutkach braku pracy, lecz także o społecznych czy nawet psychologicznych. Doświadczenia rynku pracy państw wysoko rozwiniętych świadczą o tym, że dużym problemem jest tam bezrobocie długookresowe [Budnikowski, 2009, s. 221]. Obserwacje sytuacji polskiego rynku pracy w ostatnich kilkunastu latach pokazuja, iż podobnie w Polsce jest to bardzo istotny problem społeczno-gospodarczy. Można uznać, że jest to wręcz największy problem Polski na początku XXI wieku.

Zjawisko bezrobocia ma miejsce wtedy, gdy popyt na siłę roboczą jest mniejszy od jej podaży. Głównym celem działań na rynku pracy jest doprowadzenie do tzw. pełnego zatrudnienia [Wiśniewski, 2012, s. 11]. Pełne zatrudnienie można określić jako stan rynku pracy, w którym stopa bezrobocia jest równa poziomowi bezrobocia naturalnego. Natomiast według Międzynarodowej Organizacji Pracy: petne zatrudnienie oznacza sytuacje, gdy każdy poszukujacy pracy otrzymuje oferte zatrudnienia w ciagu stosunkowo krótkiego okresu i na warunkach, co do pracy i placy, ogólnie prayjetych [Szydlik-Leszczyńska, 2012, s.18]. Zgodnie z polskim prawem, osoba bezrobotna to: osoba niezatrudniona $i$ nienylkonujaca innej pracy zarobkowej, zdolna i gotowa do podjecia zatrudnienia w petnym wymiarze czasu pracy obowiqzujacym w danym zawodzie lub slużbie albo innej pracy zarobkowej, albo jeżeli jest osoba niepetnosprawna. zdolna i gotowa do podjecia zatrudnienia co najmniej w potowie tego nymiaru czasu pracy, nienczaca sie

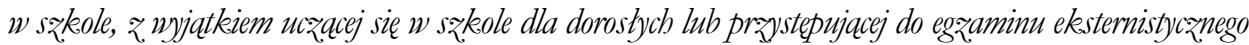

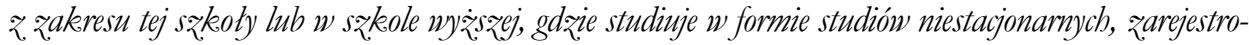
wana we wlaścinym dla miejsca zameldowania statego lub czasowego powiatonym urzedrie pracy oraz poszukijaca zatrudnienia lub innej pracy zarobkowej (...), [Ustawa o promogi zatrudnienia..., 2004 ], jeżeli spełnia podane w ustawie wymagania, m.in.: ukończyła 18 lat i nie osiagnęła wieku emerytalnego, nie jest właścicielem nieruchomości rolnej, nie złożyła wniosku o wpis do ewidencji działalności gospodarczej, nie pobiera zasiłku stałego, nie pobiera, specjalnego zasiłku opiekuńczego lub dodatku do zasiłku rodzinnego z tytułu samotnego wychowywania dziecka i utraty prawa do zasiłku dla bezrobotnych na skutek upływu ustawowego okresu jego pobierania, nie jest tymczasowo aresztowana i nie odbywa kary pozbawienia wolności. Ponadto, do kategorii bezrobotnych nie można zaliczyć osób, które w danym miesiącu uzyskały dochód w wysokości przekraczającej połowę najniższego wynagrodzenia [Budnikowski, 2009, s. 223].

W teorii ekonomii bezrobocie często jest dzielone na kategorie wyodrębnione według różnych kryteriów. Wynika to ze złożonego i wieloaspektowego charakteru tego zjawiska. W ekonomii keynesowskiej wyodrębnia się bezrobocie: frykcyjne, strukturalne i cykliczne lub także dobrowolne i przymusowe [Socha, Sztanderska, 2000, s. 15]. Bezrobocie frykcyjne jest związane $z$ naturalną dynamika rynku pracy w gospodarce rynkowej [Kwiatkowski, 2007, s. 47]. Na rynku pracy w sposób ciagły zachodzą procesy powstawania nowych oraz likwidacji istniejących miejsc pracy, na rynek wchodzą nowe roczniki osób zawodowo czynnych, a także odchodzą inne, pracujący zwalniają się i poszukują innych stanowisk pracy, ciekawszych lub znajdujących się w innym miejscu. Z tego powodu, nawet w sytuacji równoważenia się popytu na pracę i podaży pracy, na rynku może znajdować się pewna liczba wolnych miejsc pracy oraz pewna liczba osób poszu- 
kujących pracy. Ponadto, bezrobocie frykcyjne obejmuje również bezrobocie dobrowolne, czyli sytuację, gdy bezrobotni nie podejmuja zatrudnienia z różnych przyczyn ekonomicznych czy osobistych (np.: oczekiwanie na już umówioną pracę, poszukiwanie nowej pracy itp.). Dlatego też na rynku pracy zawsze występuje pewien poziom bezrobocia frykcyjnego. Zależy on m.in. od: tempa powstawania i likwidacji miejsc pracy, liczby osób wchodzących na rynek pracy i odchodzacych z rynku pracy, a także od informacji o wolnych miejscach pracy oraz osobach poszukujących pracy. Na zmniejszenie bezrobocia frykcyjnego może istotnie wpłynąć zwiększenie dostępności informacji i skuteczniejsze działanie instytucji pośrednictwa pracy [Kwiatkowski, 2007, s. 48]. Bezrobocie strukturalne można rozpatrywać w szerokim i waskim ujęciu. Szerokie znaczenie obejmuje bezrobocie frykcyjne, strukturalne sensu stricto, jak również bezrobocie instytucjonalne [Socha, Sztanderska, 2000, s. 25-27]. Bezrobocie strukturalne w waskim znaczeniu wynika z niedopasowania popytu i podaży siły roboczej na poszczególnych mikrorynkach Są one spowodowane: zmianami w strukturze popytu na towary, wdrażaniem postępu technicznego (brak odpowiednich kwalifikacji zawodowych w nowoczesnych zawodach i spadek popytu na pracowników z przestarzałymi kwalifikacjami), geograficznym rozmieszczeniem pracy i nierównomiernym rozmieszczeniem geograficznym nowego kapitału a także zmianami w strukturze towarowej handlu zagranicznego [Kwiatkowski, 2007, s. 49]. Na zmniejszenie bezrobocia strukturalnego moga oddziaływać szybsze procesy dostosowawcze do zmian w strukturach popytu i podaży pracy oraz mobilność siły roboczej. Z powyższych rozważań wynika, że bezrobocie frykcyjne i strukturalne ma pewne cechy wspólne, które są rezultatem zmian w strukturze popytu na pracę i podaży pracy, jak również niedopasowań strukturalnych. Jednak w przypadku bezrobocia frykcyjnego niedopasowanie to jest konsekwencja naturalnej dynamiki rynku pracy, zaś bezrobocie strukturalne jest skutkiem niedopasowań uwarunkowanych oddziaływaniem ekonomicznych i społecznych czynników, wywołujących zmiany w strukturze popytu na pracę i podaży pracy. Można je ograniczyć dzięki aktywnym procesom przystosowawczym, lecz w stosunku do bezrobocia strukturalnego przystosowania te są kosztowniejsze $\mathrm{i}$ bardziej długotrwałe niż w odniesieniu do bezrobocia frykcyjnego. Bezrobocie cykliczne (koniunkturalne) jest związane $\mathrm{z}$ wahaniami w poziomie globalnego popytu i aktywności gospodarczej. Niedostateczny popyt na towary przyczynia się do wzrostu bezrobocia, zaś wzrost tego popytu jest środkiem redukcji bezrobocia [Kwiatkowski, 2007, s. 58]. Natomiast w nowszych koncepcjach podkreśla się rolę ograniczeń podażowych w kształtowaniu bezrobocia. Wynika to z faktu, iż w okresach recesji zasoby czynników produkcji zmniejszają się i po zakończeniu recesji, mimo wzrostu popytu na towar, nie musi nastapić zmniejszenie bezrobocia, jeśli zasoby czynników produkcji są niewystarczające. Aby zmniejszyć bezrobocie cykliczne, nie wystarczy więc zwiększenie popytu na towary, lecz niezbędne jest zwiększenie zasobów odpowiednich czynników produkcji. Jednakże w praktyce nie zawsze jest możliwe dokładne rozgraniczenie różnych typów bezrobocia, w tym bezrobocia cyklicznego od strukturalnego. W makroekonomii podstawą dekompozycji bezrobocia na dwa niezależne składniki, cykliczny i strukturalny, jest teoria naturalnej stopy bezrobocia. Obejmuje ona bezrobocie frykcyjne oraz sensu stricto strukturalne [Socha, Sztanderska, 2000, s. 15]. Naturalna stopa bezrobocia występuje zatem przy istniejącej równowadze na rynku siły 
roboczej, gdyż zawsze pojawią się osoby, które przy danym poziomie płacy realnej nie są skłonne do podjęcia zatrudnienia (bezrobocie dobrowolne). Naturalna stopa bezrobocia może być zdefiniowana jako: stopa bezrobocia, do której dą̇y dynamičny system w warunkach struktury stochastycznej, charakterystycznej dla rómnowagi ogólnej. Uw'zglednia ona ręeczymiste, strukturalne cechy rynków pracy i rynkóow dóbr, wtacznie z ynkonymi niesprawnościami oraz kosżtami poszukiwań pracy i kosztami mobilności [Haltiwanger, 1991, s. 610]2. Mimo że istnienie długookresowej stopy bezrobocia w równowadze, niezależnej od zmian w popycie globalnym, akceptuje większość współczesnych teorii makroekonomicznych, to można w nich spotkać różne jej nazwy, definicje oraz determinanty. Wyróżnia się trzy główne nurty, wyjaśniające występowanie naturalnej stopy bezrobocia [Socha, Sztanderska, 2000, s. 16-20]. Pierwszy określa produkt i zatrudnienie jako równowagę na rynku pracy w sytuacji konkurencji doskonałej. Drugi nurt opiera się na niepełności i niedoskonałości informacji na rynku. W trzecim nurcie naturalną stopę bezrobocia traktuje się jako efekt oddziaływania czynników realnych w gospodarce, ale bazuje się na modelu rynku pracy w warunkach konkurencji niedoskonałej.

Ustalenie poziomu naturalnej stopy bezrobocia jest niezwykle trudne. W krajach o rozwiniętej gospodarce rynkowej w latach pięćdziesiątych i sześćdziesiątych XX wieku wynosiła ona 3-4\%. Optymalny model zatrudnienia zakłada poziom naturalnej stopy bezrobocia w wysokości 2-3\%. Jednakże dla gospodarek różnych krajów kształtuje się ona na innym poziomie. Nie ma jednoznacznie wyznaczonej naturalnej stopy bezrobocia dla Polski, lecz z pewnościa jest ona bliższa poziomowi 7-8\% [por. Wiśniewski, 2012, s. 11], niż wspomnianemu 3-4\% [Szydlik-Leszczyńska, 2012, s. 19]. Bezrobocie stanowi duże zagrożenie w stosunku do harmonijnego rozwoju rynku pracy w Polsce. Wielu autorów formułowało tezę, że brak miejsc pracy wynika z dużych kosztów pracy oraz istniejących z minionych czasów ochronnych przepisów prawa pracy [Gersdorf, Raczkowski, Wyziński, 2012, s. 13]. Jednak nie potwierdzają tego przeprowadzone badania. Stąd ważne jest dokładne zdiagnozowanie zjawiska bezrobocia i struktury bezrobotnych (m.in. w zależności od wykształcenia) w naszym kraju, a także opracowanie skutecznych metod przeciwdziałania. Wykształcenie jest jedną z silniejszych determinant określających szanse na znalezienie pracy [Stasiak, 2011, s. 343]. W literaturze można spotkać koncepcję zakładająca istnienie czterech efektów oddziaływania kapitału ludzkiego na pracę: pracowniczy, alokacyjny, dyfuzji oraz naukowo-badawczy [Grodzicki, 2003, s. 44]. Efekt pracowniczy, zwany efektem produktywności własnej, określa dodatnią krańcowa produktywność edukacji. Pracownik lepiej wykształcony jest bardziej efektywny, zwłaszcza w przypadku skomplikowanej techniki produkcji. Kadra o wyższym poziomie edukacji przesuwa krzywą możliwości produkcyjnych w górę. Jest to wywołane coraz bardziej złożonym procesem produkcji, przez co rosna wymagania w stosunku do poziomu wiedzy pracownika. Efekt alokacyjny zakłada konieczność wybrania procesu wytwórczego, w którym będą ulokowane środki produkcji. Wyższy poziom wykształcenia pracownika spowoduje podjęcie lepszej decyzji, a co za tym idzie, maksymalizację krańcowej wartości produkcji. Wyższe kwalifikacje obniżają także koszty zdobywania informacji i zwiększają korzyści z ich wykorzystywania. Efekt dyfuzji

${ }^{2}$ Za Socha: [Sztanderska, 2000, s. 15]. 
oznacza podniesienie stopnia akceptowalności zmian technologicznych czy organizacyjnych, w zależności od poziomu wykształcenia. Edukacja jest więc czynnikiem przyśpieszającym proces rozpowszechniania nowych technologii. Wyższy poziom edukacji powoduje podniesienie zdolności do wyboru korzystniejszych kierunków zmian, jak również minimalizuje ryzyko podjęcia błędnych decyzji. Zwiększenie liczby pracowników o wyższych kwalifikacjach przyspiesza zastosowanie nowoczesnych technologii produkcji. Efekt naukowo-badawczy podkreśla stymulowanie badań naukowych przez edukację. Wysokie kwalifikacje są niezbędne w prowadzeniu badań podstawowych oraz rozwojowych, a te sa podstawa postępu technicznego i wzrostu produktywności gospodarki. Wartość kapitału ludzkiego jest obniżana przez bezrobocie. Bezrobotny nie tylko nie tworzy nowych wartości materialnych, ale dodatkowo konsumuje wartości wytworzone przez innych. Rzeczywisty poziom bezrobocia jest trudny do oszacowania, jednak wiadomo, że wydajność pracy rośnie znacznie szybciej niż popyt na nowe produkty i usługi. Przyczynia się to zmian jakościowych w dynamice zawodów. Można zaobserwować wzrost zapotrzebowania na nowe zawody i kwalifikacje wymagające specjalistycznego kształcenia (np. w dziedzinie informatyki), natomiast zanika popyt na zawody tradycyjne (np. kowalstwo). Wykształcone społeczeństwo dąży do wielozawodowości, a także do kształcenia tzw. generalistów, zamiast specjalistów, bowiem łatwiej im będzie w przyszłości zmienić kolejny zawód i przystosować się do aktualnych potrzeb rynku pracy

W niniejszym artykule zbadano wpływ wykształcenia na poziom bezrobocia w województwie podlaskim. W analizie uwzględniono jedynie podział osób bezrobotnych ze względu na kryterium wykształcenia. Nie analizowano bezrobocia w podziale na płeć, czas pozostawania bezrobotnym, jak również nie uwzględniono przepływów zasobów siły roboczej na rynku pracy

\section{Metodologie obliczania stóp bezrobocia}

Do ilościowej analizy zjawiska bezrobocia najczęściej wykorzystuje się stopę bezrobocia. Jednak można przyjąć różne metodologie obliczania tego współczynnika. Różnią się one przyjętymi definicjami i sposobami gromadzenia danych.

Jedno z podejść do tego zjawiska jest charakteryzowane przez stope bezrobocia rejestrowanego. Wykorzystuje ona statystyki rynku pracy prowadzone przez urzędy pracy. Stopę bezrobocia rejestrowanego oblicza się jako stosunek liczby bezrobotnych zarejestrowanych do liczby cywilnej ludności aktywnej zawodowo (ogółem oraz danej grupy), tj. bez osób odbywających czynną służbę wojskową oraz pracowników jednostek budżetowych prowadzących działalność w zakresie obrony narodowej i bezpieczeństwa publicznego [Bezrobocie rejestrowane..., 2013, s. 7]. Przez pojęcie ludności aktywnej zawodowo, szacowanej na koniec każdego okresu, należy rozumieć osoby pracujące w jednostkach sektora publicznego i prywatnego, a także osoby bezrobotne. Stopę bezrobocia podaje się $z$ uwzględnieniem pracujących $w$ gospodarstwach indywidualnych w rolnictwie (będących składową cywilnej ludności aktywnej zawodowo), wyszacowanych na podstawie wyników w latach od 2004 do listopada 2010 - Naro- 
dowego Spisu Powszechnego Ludności i Mieszkań 2002 oraz Powszechnego Spisu Rolnego 2002, a od grudnia 2010 roku - Powszechnego Spisu Rolnego 2010 - GUS. Jednak stopa bezrobocia rejestrowanego jest miarą obarczona pewnymi błędami. Liczba zarejestrowanych bezrobotnych zależy od motywacji osób bezrobotnych do rejestracji w urzędzie. Jeśli szansa na znalezienie pracy za pośrednictwem urzędu pracy jest niewielka, taka motywacja nie występuje. Skutkuje to zaniżeniem faktycznej stopy bezrobocia. Z drugiej strony, jeśli bezrobotny zarejestrowany może liczyć na pewne profity, np.: udział w szkoleniach, prawo do zasiłku, powoduje to zwiększenie motywacji do rejestracji i zawyżenie faktycznej skali bezrobocia. Ponadto, zwiększenie np. wysokości zasiłku podwyższa motywację do rejestracji, zaś utrata praw do jego otrzymania może wpłynąć na zaniżenie motywacji do rejestracji.

Inna metodologię przyjmuje się, wyznaczając stopę bezrobocia według BAEL. Badanie Aktywności Ekonomicznej Ludności (BAEL) wykorzystuje metodę reprezentacyjna, która umożliwia uogólnianie wyników badania na populację generalną [Aktymmość ekonomiczna ludności..., 2013, s. 13]. Badania przeprowadza się na reprezentatywnej próbie osób w wieku 15 i więcej lat. W trakcie Badania Aktywności Ekonomicznej Ludności ustala się liczbę osób aktywnych zawodowo równą sumie pracujących i bezrobotnych. Podstawą metodologii BAEL są definicje przyjęte na XIII Międzynarodowej Konferencji Statystyków Pracy w październiku 1982 roku i zalecane do stosowania przez Międzynarodową Organizację Pracy. Przedmiotem badania jest sytuacja w zakresie aktywności ekonomicznej ludności, tzn. fakt wykonywania pracy, pozostawania bezrobotnym lub biernym zawodowo w badanym tygodniu. Wyszczególniona jest również grupa biernych zawodowo, czyli tych, których nie sklasyfikowano ani jako pracujących, ani jako bezrobotnych. Do bezrobotnych zalicza się także osoby, które znalazły pracę, czekaja na jej rozpoczęcie (do 3 miesięcy) i jednocześnie deklarowały chęć jej podjęcia. Badanie Aktywności Ekonomicznej Ludności jest prowadzone w Polsce kwartalnie od maja 1992 roku i doskonalone zgodnie z zaleceniami Eurostat. Podstawę prawną badania stanowi coroczne Rozporzadzenie Rady Ministrów w sprawie programu badan statystycznych statystyki publicznej. Podstawowym aktem prawnym, wprowadzającym Badanie Aktywności Ekonomicznej Ludności w krajach Unii Europejskiej, jest Rosporz̨adzenie Rady Unii Europejskiej $\mathrm{Nr} 577 / 98$ z dnia 9 marca 1998 roku w sprawie organizacji badania reprezentacyjnego dotyczacego sity roboczej na terenie Wspómoty. Badania Aktywności Ekonomicznej Ludności sa prowadzone od IV kwartału 1999 roku w sposób ciagły, zgodnie z metodyką Międzynarodowej Organizacji Pracy. Polegają one na ankietowaniu ogólnopolskiej próby gospodarstw domowych. Są to specyficzne badanie panelowe, w których w każdej kolejnej fali badania jest wymieniana 1/4 składu próby (tzw. panel rotacyjny). Od I kwartału 2010 roku próba do BAEL została dwukrotnie zwiększona w związku z koniecznością zapewnienia określonej precyzji w $2 \%$ dla oceny zmian stanu między kwartałami na poziomie kraju dla populacji stanowiącej $5 \%$ ludności w wieku produkcyjnym.

Według BAEL, do pracujących zalicza się wszystkie osoby w wieku 15 lat i więcej, które w okresie badanego tygodnia:

- $\quad$ wykonywały przez co najmniej 1 godzinę pracę przynoszącą zarobek lub dochód;

- prowadziły własną działalność gospodarczą poza rolnictwem; 
- $\quad$ miały pracę, ale jej nie wykonywały (z różnych przyczyn).

Do pracujących - zgodnie z międzynarodowymi standardami - zaliczani byli również uczniowie, którzy otrzymywali wynagrodzenie w ramach zawartej umowy o naukę zawodu lub przyuczenie do określonej pracy.

Aby osoba została uznana za bezrobotną według BAEL, musi spełniać następujące warunki łącznie:

- być w wieku 15-74 lata;

- nie pracować w okresie badanego tygodnia;

- $\quad$ aktywnie poszukiwać pracy (konkretne działania w okresie 4 tygodni przed badaniem, wliczając w to tydzień badania);

- $\quad$ być gotowa do podjęcia pracy w ciagu dwóch tygodni po przeprowadzeniu badania.

Według BAEL, stopa bezrobocia jest obliczana jako procentowy udział bezrobotnych w liczbie aktywnych zawodowo, uwzględniający definicje Międzynarodowej Organizacji Pracy [Aktywność ekonomiczna ludności..., 2013, s. 20]. Ta metoda liczenia stopy bezrobocia również nie jest wolna od wad. Wyniki uzyskane na podstawie badań ankietowych są obciążone błędem próby losowej. Jeśli próba losowa jest odpowiednio duża (tak się dzieje w przypadku, badań krajowych), to błąd ten jest niewielki. Jednak w szacunkach regionalnych błędy są już znaczące. Natomiast niewątpliwą zaletą takiej metodologii szacowania bezrobotnych jest standaryzacja przyjętych definicji i zasad obliczeń, co pozwala na porównywanie wyników otrzymanych dla rynków pracy różnych krajów.

Stopy bezrobocia publikowane przez GUS, obliczane według obu powyższych metodologii, podawane są najczęściej według płci, wieku, miejsca zamieszkania.

W niniejszych badaniach autorzy zaproponowali inną metodologię obliczania tego wskaźnika, będącą modyfikacją metodologii powyższych. Stopa bezrobocia została obliczona jako stosunek liczby bezrobotnych zarejestrowanych $z$ danym wykształceniem przez liczbę osób zdolnych do pracy w wieku 15-64 lata z tym samym wykształceniem:

$$
\mathrm{sbw}=\frac{\mathrm{bw}}{\mathrm{zpw}} \cdot 100 \text {, }
$$

gdzie:

sbw - stopa bezrobocia wśród osób z danym wykształceniem (\%),

bw - liczba bezrobotnych zarejestrowanych z danym wykształceniem (bezrobotni według wykształcenia), zpw - liczba osób zdolnych do pracy w wieku 15-64 lata z danym wykształceniem, przy czym:

$$
\mathrm{zpw}=\mathrm{az} \cdot \mathrm{ulw},
$$

gdzie:

az - liczba osób aktywnych zawodowo w wieku 15-64 lata (według BAEL), ulw - udziału ludności w wieku 15-64 lata, według poziomu wykształcenia w ogólnej liczbie ludności w tym wieku (według BAEL).

Liczbę osób zdolnych do pracy w wieku 15-64 lata z danym wykształceniem obliczono jako iloczyn liczby aktywnych zawodowo w wieku 15-64 lata (według BAEL) 
i udziału ludności w wieku 15-64 lata według poziomu wykształcenia w ogólnej liczbie ludności w tym wieku (według BAEL).

W artykule dokonano podziału ludności według wykształcenia:

- wyższe,

- policealne oraz średnie zawodowe,

- średnie ogólnokształcące,

- zasadnicze (zawodowe),

- gimnazjalne, podstawowe i niepełne podstawowe.

\section{Wyniki badań empirycznych}

W badaniach wykorzystano dane z Banku Danych Lokalnych, pochodzace z publikacji Głównego Urzędu Statystycznego, dostępne na stronie: www.stat.gov.pl. Analizę przeprowadzono dla kolejnych kwartałów z lat 2005-2012.

WYKRES 1.

Stopy bezrobocia dla wykształcenia wyższego w województwie podlaskim w latach 2005-2012

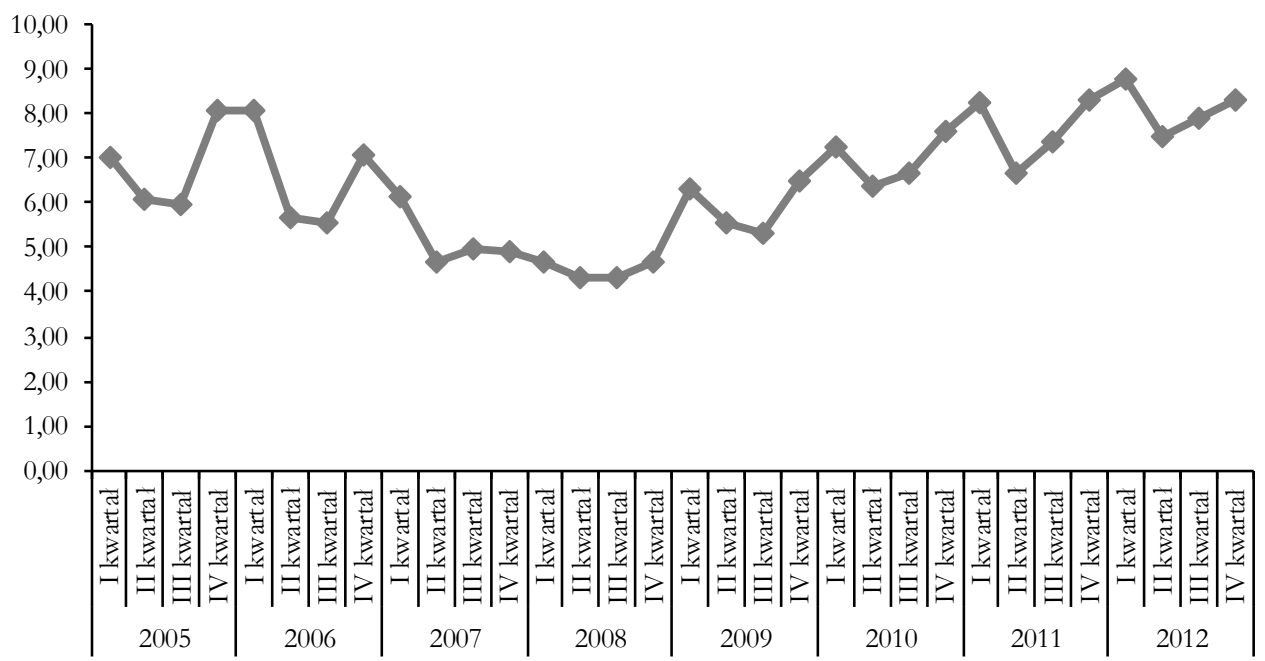

Źródło: opracowanie własne na podstawie danych GUS, dokument elektroniczny, tryb dostępu: [www.stat.gov.pl, data wejścia: 14.05.2013].

Wśród osób z wykształceniem wyższym stopa bezrobocia w badanym okresie rosła (wykres 1.). Co prawda, poczattkowo można było zauważyć spadek z 7,03\% w I kwartale 2005 roku do 4,31\% w III kwartale 2008 roku, jednak po 2008 roku wskaźnik ten 
rósł, osiagając najwyższą wartość w I kwartale 2012 - 8,8\%. Średnia wartość stopy bezrobocia wśród osób z wykształceniem wyższym w badanym okresie wynosiła $6,47 \%$. Zaskakująco wysoka była wartość współczynnika zmienności, wynosząca 20,53\%. Wyraźnie zaznaczył się więc wpływ sezonowości, co świadczy o konieczności podejmowania zatrudnienia sezonowego przez osoby z wykształceniem wyższym. Prace sezonowe na ogół są nieskomplikowane i nie wymagają wyższego wykształcenia, stąd bezrobotni $z$ tej grupy podejmowali pracę poniżej kwalifikacji. To może dowodzić tego, że na podlaskim rynku pracy jest zbyt mało ofert wymagających wyższego wykształcenia, co skutkuje podejmowaniem prac sezonowych przez osoby z takim wykształceniem. Rosnący trend analizowanego zjawiska sugeruje, że sytuacja jeszcze będzie pogarszać się. Mimo to, w tej grupie bezrobotnych stopa bezrobocia była niższa, niż wśród osób bez wykształcenia wyższego. Najłatwiej znaleźć zatrudnienie, mając wykształcenie wyższe.

WYKRES 2.

\section{Stopy bezrobocia dla wykształcenia policealnego oraz średniego zawodowe- go w województwie podlaskim w latach 2005-2012}

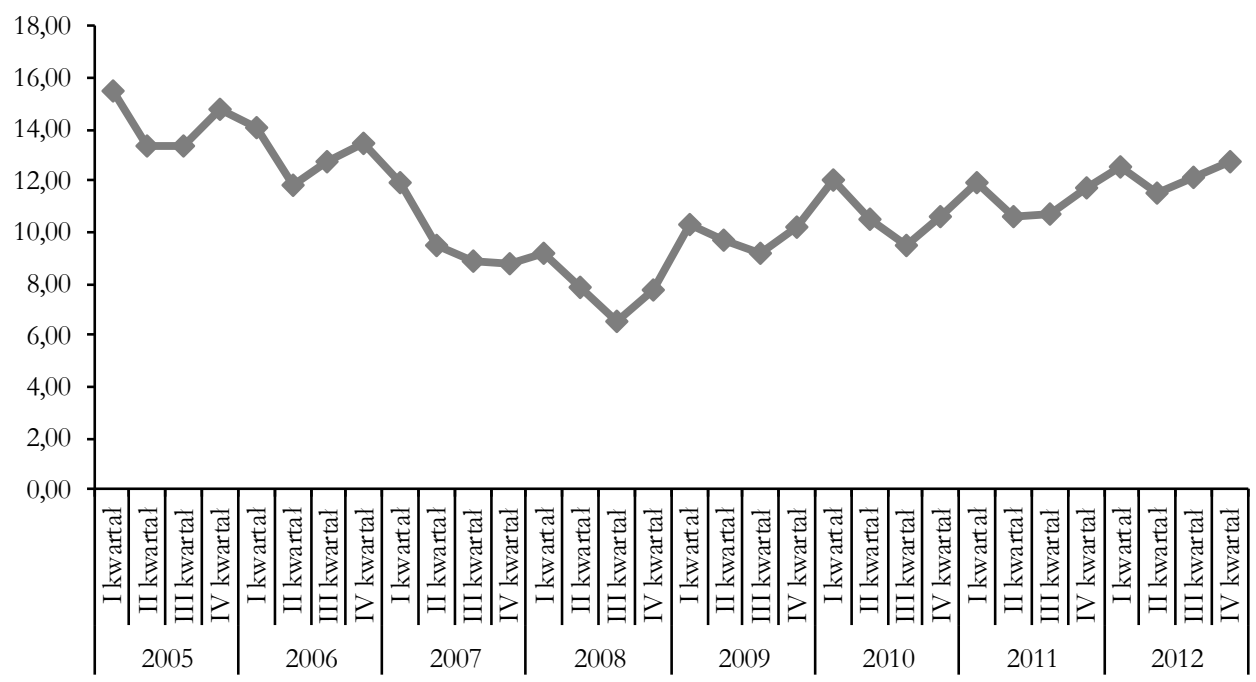

Źródło: opracowanie własne na podstawie danych GUS, dokument elektroniczny, tryb dostępu: [www.stat.gov.pl, data wejścia: 14.05.2013].

Wśród osób z wykształceniem policealnym oraz średnim zawodowym stopa bezrobocia w początkowych latach badanego okresu malała (wykres 2.). Najwyższą wartość tego współczynnika zaobserwowano w I kwartale 2005 roku (15,48\%), zaś najniższa w III kwartale 2008 roku (6,51\%). W okresie tym nastąpiło spowolnienie wzrostu gospodarczego w kraju, co skutkowało wzrostem bezrobocia również w tej grupie bezro- 
botnych. W kolejnych kwartałach stopa bezrobocia wzrastała aż do 12,69\% na koniec roku 2012. Jednak można zauważyć, że na koniec badanego okresu była niższa, niż w okresie początkowym, czyli w roku 2005. Średnia wartość stopy bezrobocia wśród osób z wykształceniem policealnym oraz średnim zawodowym wynosiła 11,1\%. Była wyższa, niż wśród osób z wykształceniem wyższym, lecz niższa niż średnia stopa bezrobocia w pozostałych analizowanych grupach bezrobotnych. Ukończenie szkoły policealnej lub średniej zawodowej daje absolwentom konkretny zawód i pewne umiejętności oraz umożliwia uzyskanie dyplomu potwierdzającego posiadane kwalifikacje zawodowe. Niższa stopa bezrobocia niż wśród bezrobotnych nieposiadających kwalifikacji oznacza, że na rynku pracy w województwie podlaskim są poszukiwani pracownicy z takim wykształceniem. Współczynnik zmienności wśród tej grupy bezrobotnych był niższy, niż w grupie $z$ wykształceniem wyższym i wynosił 19,01\%. W tej grupie bezrobotnych również można było zauważyć okresowe zmiany stopy bezrobocia, co świadczy także o podejmowaniu prac sezonowych. Jednakże można to wytłumaczyć zdobytym wykształceniem. Z pewnością część tych osób posiada zawód, na który jest zwiększone zapotrzebowanie w pewnym sezonie, np. w: budownictwie, gastronomii, rolnictwie itp.

WYKRES 3.

\section{Stopy bezrobocia dla wykształcenia średniego ogólnokształcącego w woje- wództwie podlaskim w latach 2005-2012}

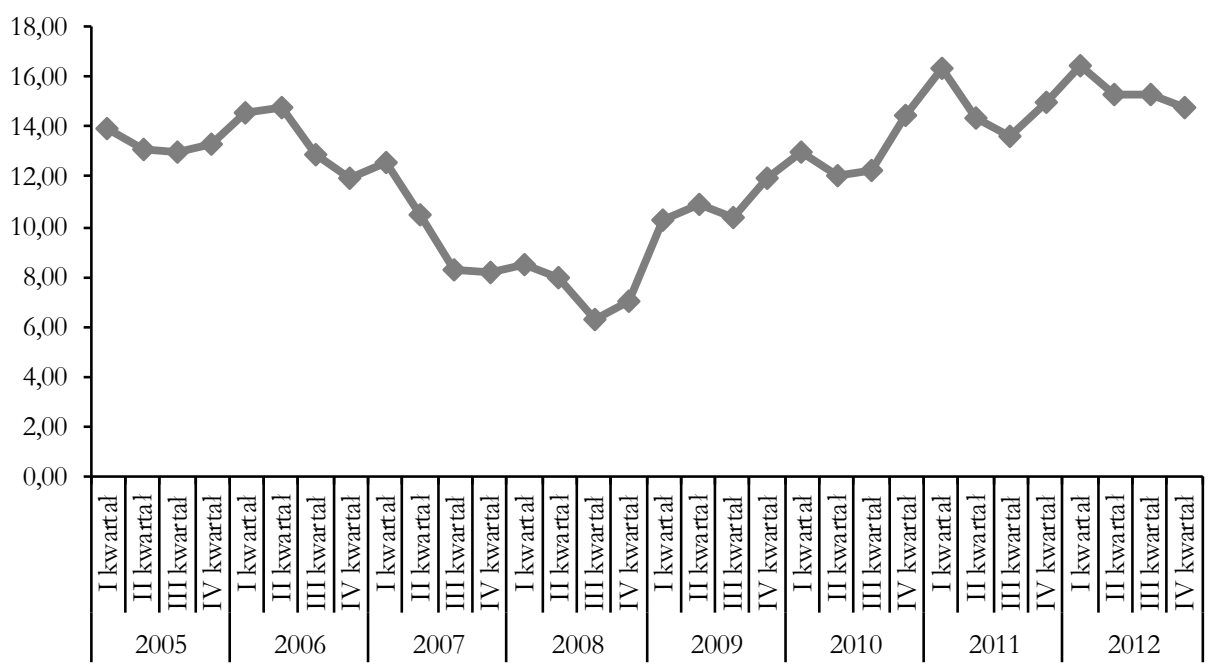

Źródło: opracowanie własne na podstawie danych GUS, dokument elektroniczny, tryb dostępu; [www.stat.gov.pl, data wejścia: 14.05.2013].

Wśród osób z wykształceniem średnim ogólnokształcącym zaobserwowano najwyższy współczynnik zmienności $(22,48 \%)$ ze wszystkich grup analizowanych według wykształcenia. Prawdopodobnie wynika to $z$ faktu podejmowania przez te osoby zatrudnie- 
nia przy pracach sezonowych (na ogół niewymagających wysokich kwalifikacji) oraz dalszego kształcenia. Wyższe stopy bezrobocia były w I i IV kwartale każdego roku, a niższe w II i III w tym samym roku. W badanym okresie stopa bezrobocia początkowo malała z 13,94\% w I kwartale 2005 roku do 6,26\% w III kwartale 2008 roku, następnie rosnąc aż do 16,41\% w pierwszym kwartale 2012 roku (wykres 3.). Można zauważyć trend rosnący, co świadczy o pogarszaniu się sytuacji na rynku pracy wśród osób z wykształceniem średnim ogólnokształcącym. Na koniec badanego okresu stopa bezrobocia była wyższa niż w roku 2005 o prawie 1,5 punktu procentowego. Średnia stopa bezrobocia wynosiła 12,28\% i była wyższa od tego współczynnika liczonego dla osób z wykształceniem policealnym oraz średnim zawodowym. W roku 2012 wartości stóp bezrobocia były prawie najwyższe ze wszystkich badanych grup. Przewyższały je jedynie stopy bezrobocia w kolejnych kwartałach tego roku, obliczone dla bezrobotnych z wykształceniem gimnazjalnym, podstawowym i niepełnym podstawowym. Oznacza to brak w województwie podlaskim ofert pracy dla osób nieposiadających konkretnych kwalifikacji zawodowych, mimo zdobytego wykształcenia średniego. Jak się okazuje, bardziej poszukiwani są pracownicy posiadający pewne umiejętności nawet na poziomie średnim zawodowym czy zasadniczym zawodowym.

WYKRES 4.

Stopy bezrobocia dla wykształcenia zasadniczego zawodowego w województwie podlaskim w latach 2005-2012

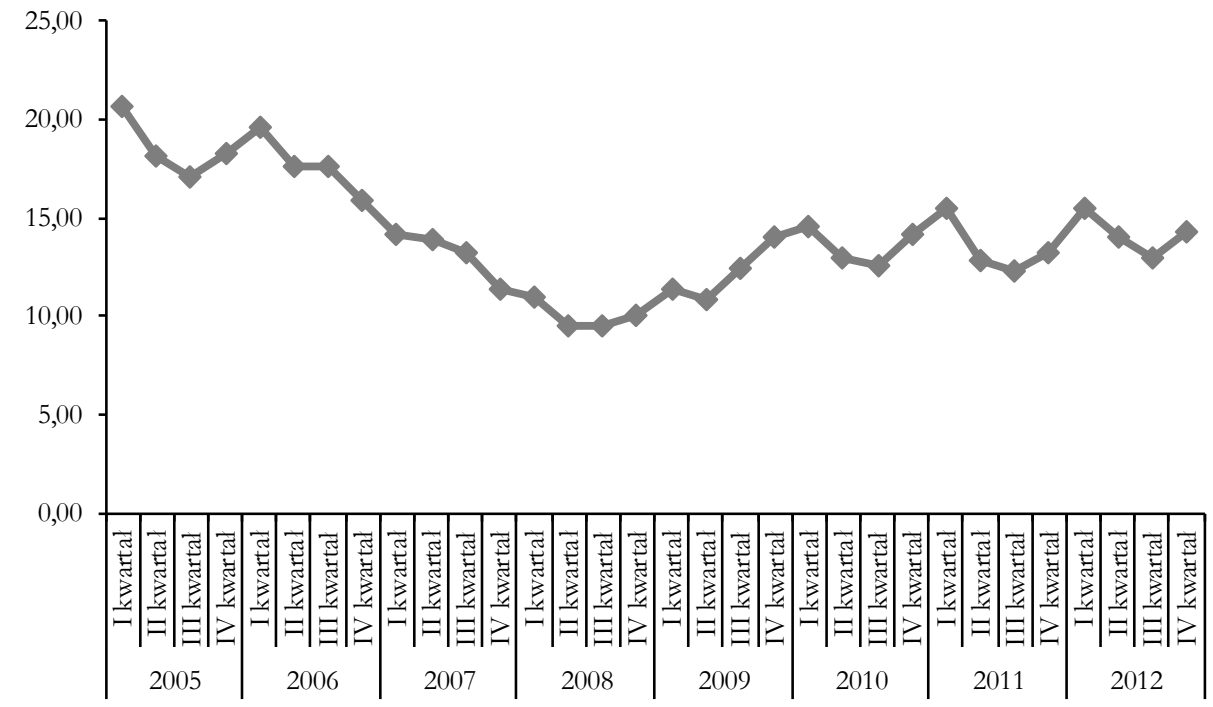

Źródło: opracowanie własne na podstawie danych GUS, dokumente elektroniczny, tryb dostępu: [www.stat.gov.pl, data wejścia: 14.05.2013]. 
W analizowanym okresie można zauważyć malejący trend stóp bezrobocia wśród osób z wykształceniem zasadniczym zawodowym (wykres 4.). Najwyższa wartość objęła 1 kwartał 2005 roku (20,65\%), zaś najniższa 9,53\% dotyczyła II i III kwartału 2008 roku. Po roku 2008 stopa bezrobocia rosła, lecz nie osiagnęła wartości z roku 2005. W I kwartale 2012 roku stopa bezrobocia wśród tej grupy bezrobotnych wynosiła 15,41\%, czyli na koniec badanego okresu współczynniki te nie osiagnęły wartości z analogicznych kwartałów w roku 2005. Współczynnik zmienności w analizowanym okresie był na poziomie 20,04\%. Jednak na podstawie tego wykresu można zauważyć mniejszy wpływ sezonowości. Świadczy to o stałym, choć niewielkim, wzroście zapotrzebowania na pracowników posiadających wykształcenie zasadnicze zawodowe. Takie wykształcenie, podobnie jak wykształcenie policealne i średnie zawodowe, zapewnia pracownikom odpowiednie kwalifikacje, niezbędne do wykonywania wielu zawodów. Wśród nich są również zawody, na które rynek pracy zgłasza zapotrzebowanie sezonowo. Wyższa niż w grupie bezrobotnych z wykształceniem policealnym oraz średnim zawodowym średnia stopa bezrobocia pokazuje, że pracodawcy mniej chętnie zatrudniaja pracowników z takim wykształceniem, mimo posiadania odpowiednich kwalifikacji zawodowych. Jednakże, dający się zaobserwować, trend malejący może sugerować poprawę sytuacji na podlaskim rynku pracy wśród osób z wykształceniem zasadniczym zawodowym.

WYKRES 5.

Stopy bezrobocia dla wykształcenia gimnazjalnego, podstawowego i niepełnego podstawowego w województwie podlaskim w latach 2005-2012

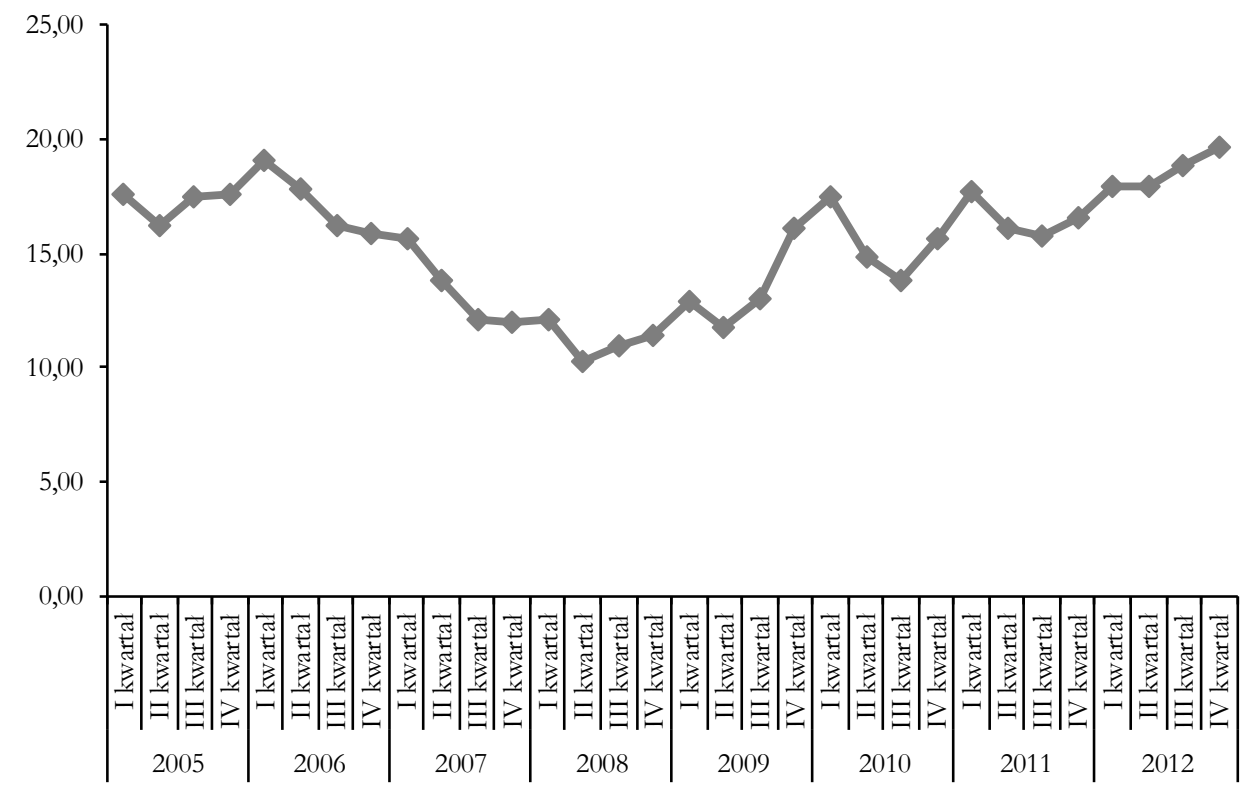

Źródło: opracowanie własne na podstawie danych GUS, dokument elektroniczny, tryb dostępu: [www.stat.gov.pl, data wejścia: 14.05.2013]. 
Wśród osób z wykształceniem gimnazjalnym, podstawowym i niepełnym podstawowym w badanym okresie stopa bezrobocia kształtowała się na poziomie od $17,58 \%$ w I kwartale 2005 roku, poprzez 10,3\% w II kwartale 2008 roku, aż po 19,62\% w IV kwartale 2012 roku (wykres 5.). Można zauważyć wyraźny trend rosnący. Na koniec badanego okresu (IV kwartał 2012 roku) współczynnik ten był ponad 2 punkty procentowe wyższy, niż w analogicznym okresie 2005 roku. Współczynnik zmienności wynoszący $17,14 \%$ oraz analiza wykresu pokazują, że wśród tej grupy bezrobotnych stopa bezrobocia $\mathrm{w}$ niewielkim stopniu podlegała sezonowości. Podlaski rynek pracy nie oferował zatrudnienia, nawet sezonowego, osobom, o których można powiedzieć, że właściwie nie są wykształcone. W tej grupie bezrobocie było najwyższe w porównaniu z innymi, analizowanymi grupami. Średnia stopa bezrobocia w badanym okresie wynosiła 15,37\% i była najwyższa ze wszystkich średnich liczonych dla wyodrębnionych grup bezrobotnych według wykształcenia.

\section{Podsumowanie}

Przeprowadzone badania objęły kolejne kwartały lat 2005-2012. Dokonano obliczeń stóp bezrobocia w województwie podlaskim ze względu na wykształcenie bezrobotnych: wyższe, policealne i średnie zawodowe, średnie ogólnokształcące, zasadnicze (zawodowe) oraz gimnazjalne, podstawowe i niepełne podstawowe. Podsumowując analizę przeprowadzonych badań, można sformułować następujące wnioski:

1. W latach 2005-2008 stopy bezrobocia na Podlasiu, niezależnie od wykształcenia bezrobotnych, malały, osiagając swój najniższy poziom w roku 2008 (wykres 6.). W tym okresie stopy bezrobocia wśród bezrobotnych z wykształceniem gimnazjalnym, podstawowym i niepełnym podstawowym kształtowały się prawie identycznie jak stopy bezrobocia wśród bezrobotnych z wykształceniem zasadniczym (zawodowym). Największa różnica między nimi była w I kwartale 2005 roku i wynosiła 3,07 punktu procentowego. Jednak były to najwyższe stopy bezrobocia wśród wszystkich analizowanych w tym okresie. Można więc stwierdzić, że w latach 2005-2008 im wyższe wykształcenie (więcej lat edukacji) miał poszukujący pracy, tym większa była szansa na jej znalezienie. W związku z tym, im więcej lat poświęcono na edukację, tym niższe były stopy bezrobocia. Natomiast stopy bezrobocia wśród bezrobotnych z wykształceniem średnim ogólnokształcącym kształtowały się prawie identycznie jak stopy bezrobocia wśród bezrobotnych z wykształceniem policealnym oraz średnim zawodowym. Różnice między nimi w tym okresie nie przekraczały 3 punktów procentowych (największa różnica była w II kwartale 2006 roku i wynosiła 2,88 punktu procentowego). Były one wyższe niż stopy bezrobocia osób z wykształceniem wyższym i niższe od pozostałych;

2. W latach 2009-2012 stopy bezrobocia w województwie podlaskim rosły niezależnie od wykształcenia (wykres 6.). Nadal najniższe były stopy bezrobocia wśród bezrobotnych $z$ wykształceniem wyższym, lecz można zauważyć, że pojawiły się duże różnice stóp bezrobocia w grupach, w których w latach 
wcześniejszych kształtowały się bardzo podobnie. Gwałtownie wzrosła stopa bezrobocia wśród osób z wykształceniem średnim ogólnokształcącym. Jej wartości zbliżyły się do stóp bezrobocia w grupie bezrobotnych z wykształceniem zasadniczym (zawodowym), nawet je przekraczając od roku 2011. Stopy te były dużo wyższe od stóp bezrobocia bezrobotnych z wykształceniem policealnym oraz średnim zawodowym. Przykładowo, różnica między nimi w I kwartale 2011 roku wynosiła 4,43 punktu procentowego (warto pamiętać, że w latach 2005-2008 miały bardzo zbliżone wartości). W okresie tym znaczaco wzrosły także stopy bezrobocia wśród osób z wykształceniem gimnazjalnym, podstawowym i niepełnym podstawowym. Ich wartości od roku 2011 znacznie przekroczyły stopy bezrobocia wśród bezrobotnych z wykształceniem zasadniczym (zawodowym). Różnica między nimi w IV kwartale 2012 roku wynosiła aż 5,37 punktu procentowego. Jak już wspomniano wcześniej, tak duży wzrost analizowanych współczynników w grupach z wykształceniem gimnazjalnym, podstawowym i niepełnym podstawowym, jak również średnim ogólnokształcącym z jednoczesnym mniejszym wzrostem stóp w grupach z wykształceniem zasadniczym (zawodowym) i policealnym oraz średnim zawodowym świadczy o wzroście ofert pracy dla osób posiadajacych pewne kwalifikacje zawodowe, a braku ofert pracy dla osób nieposiadajacych takich kwalifikacji;

3. Stopy bezrobocia w województwie podlaskim w latach 2005-2012 charakteryzowały się sezonowością, w I i IV kwartale każdego roku były wyższe niż w II i III kwartale danego roku (wykres 6.). I i IV kwartał roku to okres jesienno-zimowy. W tym czasie znacząco zmniejszył się popyt na pracowników w takich działach gospodarki, jak np.: budownictwo, rolnictwo, turystyka. W województwie podlaskim są to prężnie rozwijajace się gałęzie, stąd wzrost stóp bezrobocia w tym sezonie. Zastanawiający jest wpływ sezonowości na stopy bezrobocia wśród osób z wykształceniem wyższym. Jak już zauważono wcześniej, może to dowodzić podejmowania przez te osoby prac sezonowych, czyli prawdopodobnie poniżej ich kwalifikacji zawodowych. Można więc wysnuć wniosek, że zbyt mało jest ofert dla absolwentów wyższych uczelni na podlaskim rynku pracy. Tak wiele działających tu wyższych uczelni (publicznych i niepublicznych) oraz stosunkowo niski rozwój przemysłu na tym terenie generuje liczne grono bezrobotnych z wykształceniem wyższym;

4. Najniższe stopy bezrobocia w analizowanym okresie były w II/III kwartale 2008 roku (wykres 6.). Od tego momentu obserwuje się spowolnienie wzrostu gospodarczego, czego skutkiem jest wzrost bezrobocia wśród wszystkich analizowanych grup. Jednocześnie w Polsce II i III kwartał to pory roku, w których pojawiają się prace sezonowe, dzięki którym rokrocznie wielu bezrobotnych znajduje zatrudnienie. Co ciekawe, mimo że w III kwartale każdego roku na rynku pracy pojawiają się absolwenci (na każdym poziomie kształcenia), w tym właśnie okresie stopa bezrobocia w badanych grupach była najniższa (w roku 2008), jedynie w grupie bezrobotnych z wykształceniem gimnazjalnym, podstawowym i niepełnym podstawowym najniższa stopa 
bezrobocia była w II kwartale. Pozytywnie świadczy to o wspomnianych młodych ludziach, którzy po skończeniu edukacji (niezależnie od poziomu) potrafią odnaleźć się na podlaskim rynku pracy. Jednak często jest to zatrudnienie sezonowe bez możliwości kontynuowania w IV kwartale roku;

5. Najwyższe stopy bezrobocia dla bezrobotnych $z$ wykształceniem policealnym oraz średnim zawodowym, a także zasadniczym (zawodowym) objęły I kwartał 2005 roku (wykres 6.). Innymi słowy, mimo wzrostu stóp po roku 2008 na koniec badanego okresu, analizowane współczynniki nie osiagnęły swoich poziomów z okresu początkowego. Można więc prognozować korzystne trendy dla osób z tym właśnie wykształceniem, czyli posiadających kwalifikacje zawodowe. Natomiast dla bezrobotnych $z$ wykształceniem wyższym i średnim ogólnokształcącym najwyższe stopy bezrobocia miały miejsce w I kwartale 2012 roku, zaś z wykształceniem gimnazjalnym, podstawowym i niepełnym podstawowym w IV kwartale tego roku. Wartości analizowanego współczynnika na koniec badanego okresu przewyższały zatem swoje początkowe wielkości. O ile nie dziwi taki wzrost bezrobocia wśród osób bez kwalifikacji zawodowych, gdyż nie są to pracownicy poszukiwani na rynku pracy, o tyle zastanawiający i niekorzystny jest wzrost bezrobocia wśród absolwentów wyższych uczelni. Jakkolwiek ciagle w tej grupie bezrobocie jest najniższe, to, jeśli taki niekorzystny trend się utrzyma, sytuacja może się zmienić;

6. Współczynniki zmienności stóp bezrobocia w analizowanym okresie kształtowały się na poziomie około $20 \%$, od $17,14 \%$ dla wykształcenia gimnazjalnego, podstawowego i niepełnego podstawowego do $22,48 \%$ dla średniego ogólnokształcącego. Potwierdza to, opisany już wcześniej, duży wpływ wahań sezonowych na rynek pracy w województwie podlaskim;

7. Najwyższa średnia stopa bezrobocia w badanym okresie wynosiła $15,37 \%$ i dotyczyła osób z wykształceniem gimnazjalnym, podstawowym i niepełnym podstawowym. Biorąc pod uwagę ten fakt oraz rosnący trend stóp bezrobocia w tej grupie (od roku 2008 charakteryzuje się ona najwyższą stopą bezrobocia wśród wszystkich analizowanych), można stwierdzić, że ukończenie edukacji na tak niskim poziomie dyskwalifikuje te osoby na rynku pracy. Niewiele niższa jest średnia wśród bezrobotnych z wykształceniem zasadniczym (zawodowym) $-14,08 \%$. Jednak uwzględniając korzystny kierunek zmian bezrobocia w tej grupie (od I kwartału 2005 roku do IV kwartału roku 2012 zmalała o 6,4 punktu procentowego), warto zauważyć, że ciagle jest popyt na pracowników z niższym wykształceniem, lecz posiadających pewne umiejętności. Średnie stopy bezrobocia wśród osób z wykształceniem średnim ogólnokształcacym, policealnym oraz średnim zawodowym wynosiły odpowiednio 12,28\% i 11,1\%. Mimo że różnią się one o mniej niż 1,2 punktu procentowego, w grupach tych zaobserwowano odmienne tendencje zmian. Bezrobotnych z wykształceniem średnim ogólnokształcącym przybyło, co oznacza, że zakończenie edukacji na etapie maturalnym jest zdecydowanie niewystarczające, by odnaleźć się na podlaskim rynku pracy. Natomiast liczba bezrobotnych z wykształceniem policealnym oraz średnim zawodowym zmalała, co 
pozwala wnioskować, że osoby z takim wykształceniem mają szansę, aby zaistnieć na rynku pracy i jeżeli zaobserwowana tendencja się utrzyma, ich sytuacja może nawet ulec poprawie. Najniższa średnia stopa bezrobocia w badanym okresie wynosiła $6,47 \%$ i dotyczyła osób z wykształceniem wyższym. Uwzględnienie niekorzystnego, rosnącego trendu tych współczynników w ostatnich latach skłania do przypuszczeń, że jeśli gospodarka Podlasia nie zacznie gwałtownie rozwijać się, bezrobotnych z wykształceniem wyższym będzie przybywać. Istnieje także duże prawdopodobieństwo, że dobrze wykształceni przez podlaskie uczelnie absolwenci będa poszukiwać zatrudnienia w innych województwach lub poza granicami kraju.

WYKRES 6.

\section{Stopy bezrobocia według wykształcenia $\mathrm{w}$ województwie podlaskim w la-} tach 2005-2012

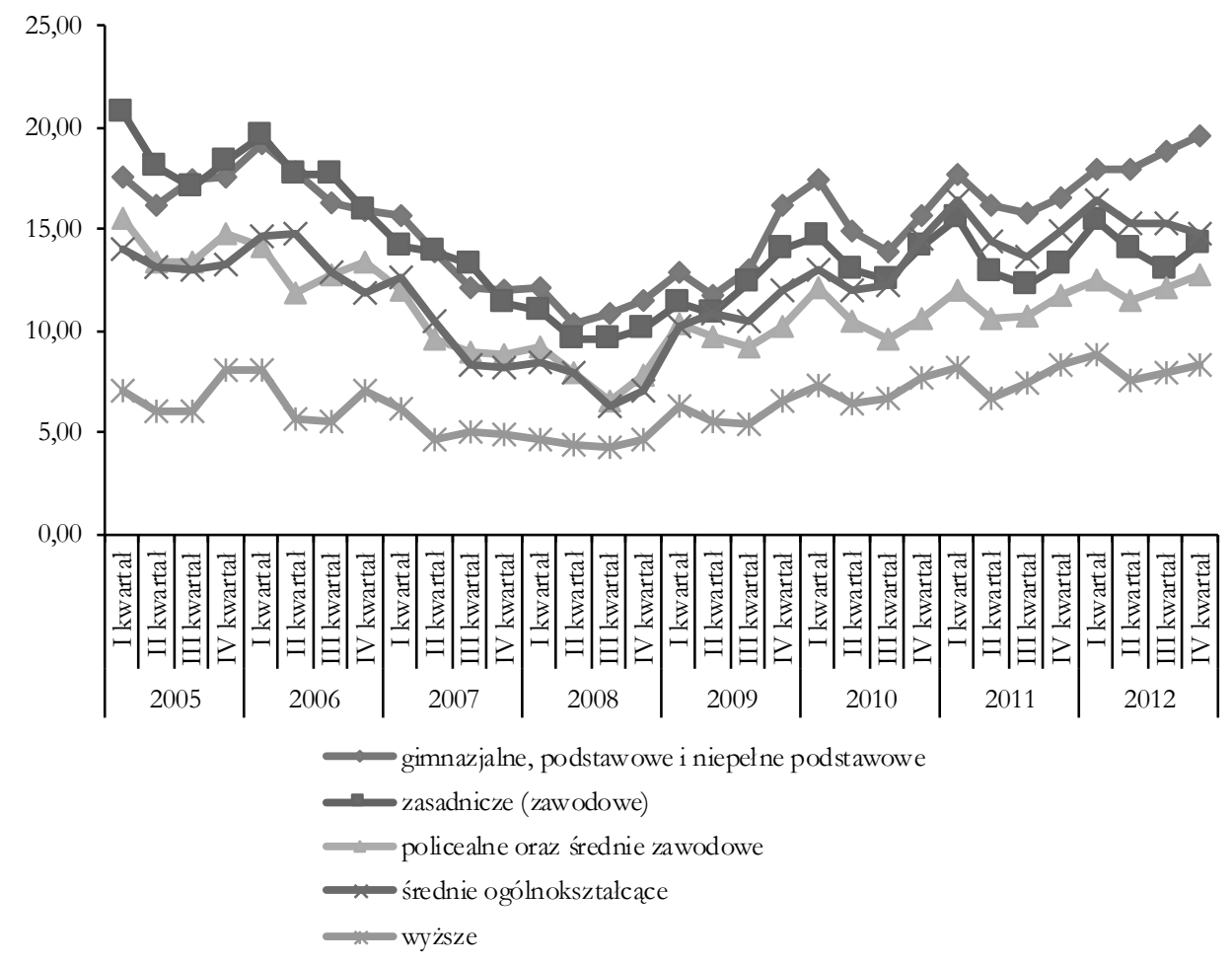

Źródło: opracowanie własne na podstawie danych GUS, dokument elektroniczny, tryb dostępu: [www.stat.gov.pl, data wejścia: 14.05.2013].

Na zakończenie można więc stwierdzić, że w województwie podlaskim wyższe wykształcenie determinuje większe szanse na rynku pracy, lecz nie można zgodzić 
się z popularnym dość stwierdzeniem, że stopa bezrobocia maleje wraz ze wærostem poziomu wyksstałcenia [Klonowska-Matynia, Radlińska, 2009, s. 107]. Badania wykazały, że w ostatnich latach na Podlasiu wśród osób z wykształceniem średnim ogólnokształcacym zaobserwowano wyższą stopę bezrobocia niż wśród grupy z wykształceniem zasadniczym (zawodowym). Wynika stąd postulat, że szkoły kształcące na poziomie zawodowym, tak chętnie likwidowane w latach dziewięćdziesiatych XX wieku [Stasiak, 2011, s. 345], powinny zostać przywrócone, gdyż kształca pracowników poszukiwanych na rynku pracy. Szansa jest, obowiązująca od 1 września 2012 roku, reforma szkolnictwa zawodowego. Będzie wymagało to oczywiście dużych nakładów finansowych, ponieważ należy je przygotować do potrzeb aktualnego rynku pracy, jednak w dłuższym okresie przyczyni się z pewnością do wzrostu konkurencyjności oraz produktywności polskiej gospodarki.

Wnioski zaprezentowane w powyższym artykule oparto na przeprowadzonych badaniach, dotyczących rynku pracy województwa podlaskiego w latach 2005-2012. Dokonano analizy zmiany stopy bezrobocia w tym województwie ze względu na wykształcenie, niezależnie od przepływów zasobów siły roboczej na rynku pracy.

\section{Literatura}

Aktywność ekonomiczna ludności Polski IV kewartał 2012 2013, GUS, Warszawa.

Bearobocie rejestrowane I-IV kwartat 2012 rok 2013, GUS, Warszawa.

Budnikowski T. 2009 Bezrobocie wyzpwaniem wspótczesności, Instytut Zachodni, Poznań.

Dokument elektroniczny, tryb dostępu: [http://www.stat.gov.pl/bdl/app/strona. html?p_name=indeks, data wejścia: 14.05. 2013].

Gersdorf M., Raczkowski M., Wyziński R. 2012 Zatrudnieni $i$ zatrudniajacy na aktualnym rynku pracy, Wydawnictwo LexisNexis, Warszawa.

Grodzicki J. 2003 Rola kapitalu ludzkiego w rozwoju gospodarki globalnej, Wydawnictwo Uniwersytetu Gdańskiego, Gdańsk.

Haltiwanger J. 1991 The Natural Rate of Unemployment, [in:] The New Palgrave. A Dictionary of Economics. T. 3, The Macmillan Press LTD, London.

Klonowska-Matynia M., Radlińska K. 2009 Rola ksztatcenia kapitału ludzkiego wobec potrzeb rynku pracy w obszarze MSP w Polsce, [w:] Rynek, pracy w Polsce w dobie integracji europejskiej i globalizacji, M. Noga, M. K. Stawicka (red.), Wydawnictwo CeDeWu, Warszawa.

Kozek W. 2013 Rynek pracy. Perspektywa instytucjonalna, WUW, Warszawa.

Kwiatkowski E. 2007 Bezrobocie. Podstany teoretyczne, PWN, Warszawa.

Socha M., Sztanderska U. 2000 Strukturalne podstawy bezrobocia w Polsce, Wydawnictwo Naukowe, Warszawa.

Stasiak J. 2011 System edukacji wobec myzwań rynku pracy w Polsce, [w:] Konkurencyjność i innowacyjnośc gospodarki a bearobocie, „Folia Oeconomica”, 248, Wydawnictwo Uniwersytetu Lódzkiego, Łódź. 
Szydlik-Leszczyńska A. 2012 Funkcjonowanie wspótçesnego rynku pracy. Wybrane uwarunkowania, Difin, Warszawa.

Ustawa o promogi zatrudnienia i instytucjach rynku pracy z dn. 20 kwietnia 2004 roku z późn. zmianami.

Wiśniewski Z. 2012 Aktywna polityka rynku pracy, [w:] Metody i narz̨edzia badania efektywności aktywnej politykei rynku pracy, M. Maksim, Z. Wiśniewski (red.), Wydawnictwo Centrum Rozwoju Zasobów Ludzkich, Warszawa. 